\title{
Spatio-Statistical Analysis of Rainfall and Temperature Distribution, Anomaly and Trend in Nigeria
}

\author{
Elisha Ademola Adeleke* and Eniola Aminat Orebayo \\ Department of Geography \& Environmental Management, University of Ilorin, Ilorin, \\ 1515, Nigeria \\ *Corresponding Author: adelekeelisha@yahoo.com
}

Received 3 June 2019/ Revised 16 May 2020 / Accepted 14 June 2020/ Available Online 23 July 2020

\begin{abstract}
This study aims to examine the variability of rainfall and temperature based on spatiostatistical analysis. Data for the study was gotten from the Nigerian Meteorological Agency and subjected to statistical analysis using mean, standard deviation, time series analysis, t-test and correlation. The results of the study revealed that the mean rainfall in the area is $108.6 \mathrm{~mm}$, mean temperature is $28^{\circ} \mathrm{C}$ and mean sunshine is 4.7 hours. The result further revealed that mean onset date in the state is $13^{\text {th }}$ march, mean cessation date is $10^{\text {th }}$ October while the mean length of rainy season is 223 days. The result also showed that rainfall anomaly index in the area ranged between -2.12 and 2.28 while temperature anomaly ranged between -2.31 and 1.73 . The correlation coefficient showed that cessation (0.408) and Length of rainy season (0.406) is significantly related to rainfall, sunshine hours $(0.380)$ and average temperature $(0.867)$ is significantly related to minimum temperature, sunshine hours (-0.389) and average temperature $(0.749)$ is significantly related to maximum temperature while onset $(-0.642)$ and cessation $(0.509)$ is significantly related to length of rainy season. However, there is a significant difference in onset dates, cessation dates and length of rainy season in the area. The area is experiencing a significant increase in temperature, rainfall and sunshine hours and recommends that more tress should be planted in the area and Nigerian meteorological agency should also inform farmers about the onset of the rains so as to help the farmers prepare for the planting season.
\end{abstract}

Keywords: Climate; Rainfall; Anomaly; Temperature; Cessation; Onset 
E.A. Adeleke and E.A. Orebayo et al / GEOSI Vol 5 No 2 (2020) 226-249

\section{Introduction}

Rainfall is one of the major factors affecting food security especially in countries largely or highly dependent on rain-fed agriculture, given that, in addition to evaporation rate and soil characteristics, it controls the state of soil moisture. The role of moisture in agricultural production is even more important in the tropics, especially Nigeria, where rainfall is highly seasonal over most parts and varies from year to year, while the growing season is determined by the availability of rain to meet crop water requirements (Odekunle, 2004).

The amount of rainfall that is normally received determines which types of agriculture that can be carried out and which crops can be cultivated in a region. The seasonal distribution of rainfall regulates the agricultural calendar in the tropics (Vellinga et al., 2013). The relationship that exists between rainfall and the tropical occupation of agriculture in Nigeria is that it employs over $80 \%$ of the work force. Rainfall is arguably the most important meteorological parameter that has the greatest impact on human activity. Rainfall distribution and pattern has been a major concern to different people in diverse field. i.e. to the agriculturist, rainfall is a crucial factor that determines the planting season and influences the type of crops to be cultivated. To the hydrologist, rainfall is important in generation of Hydro Electric Power. The volume of water in rivers increases during the rainy season and this boost generation of electricity.

More actions should be taken to sensitize the public about the occurrences of weather events, which is frequent nowadays as evidence of change in the climate (Ayanlade et al., 2020). Rainfall in Nigeria is produced by the intertropical discontinuity. Tropical analysts have consequently identified the boundary by several names such as The Intertropical Convergence Zone (ITCZ), Intertropical Fronts (ITF), and recently the Intertropical Discontinuity (ITD). The ITD is a warm, moist maritime air masses yielding heavy rainfall. Rainfall is copious in all mouths with an annual total often being $250 \mathrm{~cm}$ (Strahler \& Strahler, 1988). It is primarily a region of "maximum" Surface moisture gradient, known as a humidity discontinuity (Oyewo, 2005). 
E.A. Adeleke and E.A. Orebayo et al / GEOSI Vol 5 No 2 (2020) 226-249

Reduction in volume of rainfall and significant increase in surface temperature with the farmers having firm perception of these changes (Tarfa et al., 2020). Warmer temperatures are very likely to produce more vigorous variability in climate such as increase evaporation, capacity of air to hold more moisture and thus heavier rainstorms.

Growing industrialization and increasing use of fossil fuels are putting pressure and affecting the regional and global temperatures that are subsequently influencing the overall precipitation levels. Increasing temperature and changing patterns of precipitation are among the many consequences, which are attributed to climate change (Dammo et al., 2016). A change in temperature is an important indicator of global warming that directly determines the impact of climate change. Recent concern about rising global temperature was justified by its negative impact in all sectors of the economy most especially water supply, ecosystems, coastal habitats, and industries. Climate change could alter groundwater mainly through changes in the recharge, leading to modify groundwater levels (Guevara-Ochoa et al., 2020).

Analysis of the responses to questions on perceptions of extreme climate effects indicated that about $70 \%$ of the farmers were aware of the effects of extreme climate events on crop production and yield, and over 50\% indicated that too early rainfall, late rainfall, prolonged dryness after an initial rainfall, excessive rainfall, windstorms were the common weather-related causes of low crop yields (Eludoyin et al., 2017). Oceanic and/or atmospheric influences on the rainfall in Benin were examined by investigating the correlation between the precipitation time series and several indices (Ahokpossi, 2018).

Furthermore, the report on cessation of the rainy season in the country indicated changes from "normal" between 1941 and 1970 to "early cessation" during the 1971 to 2000 period in most stations (NIMET, 2008). NIMET (2012) as certained that the period of the rainy season in the country has decline from 1941 while the signals of late onset and early cessation of the rainy season set in. Thus, the length of the rainy season has remained shrinking, the annual total rainfall is almost the same, thereby giving rise to 
E.A. Adeleke and E.A. Orebayo et al / GEOSI Vol 5 No 2 (2020) 226-249

occasional flash floods and drought occurrences during growing period. Temperatures across the country showed an increasing trend from mid- $20^{\text {th }}$ century to date. The mean temperature anomaly indicated warming in most locations in the country. Temperatures have increased from 0.2 to $0.5^{\circ} \mathrm{C}$ in the high ground areas of Jos, Yelwa and Ilorin in the north and Shaki, Iseyin and Ondo in the southwest to 0.9 to $1.9^{\circ} \mathrm{C}$ over the rest parts of the country. Aiyelokun \& Odekoya (2016) stated that the temperature regimes from 1983 to 2013 in Ijebu Ode appears to be varying and changing statistically. Furthermore, average temperature in Ijebu Ode is high in the dry season and low in the wet season and temperature is generally low during August break when rainfall seizes (Aiyelokun \& Odekoya, 2016).

The watershed has been suffering from irregular and erratic rainfall during the dry season. Temperature exhibited a statistically significant rising trend with minimum temperature rises faster than that of the maximum temperature (Ketema \& Siddaramaiah, 2020). Trend for mean and minimum average temperatures through time significantly while the trend for maximum temperature exhibited a nonsignificant increasing trend (Asfaw et al., 2018). Factors that mainly correlate with stream flow are precipitation and maximum temperature (Tesfaye et al., 2017). A warming process and an acceleration of the atmospheric evaporative demand which took place especially since the mid-1970s (Elferchichi et al., 2017)

Rice yield and temperature had generally statistically significant positive trends, adaptation strategies to genetically modify rice varieties and effective water use strategies in areas of rainfall deficit are recommended to ensure food security (Akinbile et al., 2020). Warm extreme days are associated with midtropospheric sub sidence motion in vertical velocity anomaly that is connected with the core of the thermal low and the net convergent flow in Nigeria (Abatan et al., 2019). The trends in cold nights are larger than for cold days at both the annual and seasonal scales in Nigeria (Abatan et al., 2016). An increasing trend in both rainfall and temperature in annual statistics, though statistically insignificant (Umar et al., 2019) 
E.A. Adeleke and E.A. Orebayo et al / GEOSI Vol 5 No 2 (2020) 226-249

The high variations of rainfall at higher latitudes reveal the unreliable nature of rain fall as one progresses towards Northern Guinea and vice versa (Buba et al., 2017). The observed spatiotemporal trends and variability in rainfall are important basis for guiding targeting of appropriate adaptive measures across multiple sectors (Muthoni et al., 2019). There have been limited studies concerned on spatio-statistical analysis of rainfall and temperature. Therefore, this research intends to rainfall and temperature analysis based on onset, cessation and length of rainy season. This study aims to examine the variability of rainfall and temperature based on spatio-statistical analysis.

\section{Methods}

\subsection{Study Area}

The study area is Ijebu Ode in ogun state, Nigeria (Figure 1 and 2). The area experiences humid tropical climate which is characterized by alternate wet and dry season seasons like the rest of Nigeria. Ijebu-Ode region on annual basis is under the influence of hot-wet tropical maritime air mass during the rainy season (April-October) and hot-dry tropical continental air mass during the dry season (November-March) (Aiyelokun \& Odekoya, 2016). Rainfall is generally heavy with peaks occurring in July and September (double maxima) coupled with high temperature, high evapotranspiration and high relative humidity. The average monthly rainfall for the area ranges between $7.1 \mathrm{~mm}$ in the month of January to $208.27 \mathrm{~mm}$ in the month of June. The annual rainfall is between $1575 \mathrm{~mm}$ and $2340 \mathrm{~mm}$. The temperature of the area ranges from $23^{\circ} \mathrm{C}$ during the dry season to $35^{\circ} \mathrm{C}$ during the rainy season with an average annual temperature is $27.5^{\circ} \mathrm{C}$. Furthermore, the area experiences relative humidity of $63 \%$ in the dry season to as high as $95 \%$ during the peak of the rainy season (Onakomaiya, 2000). 
E.A. Adeleke and E.A. Orebayo et al / GEOSI Vol 5 No 2 (2020) 226-249

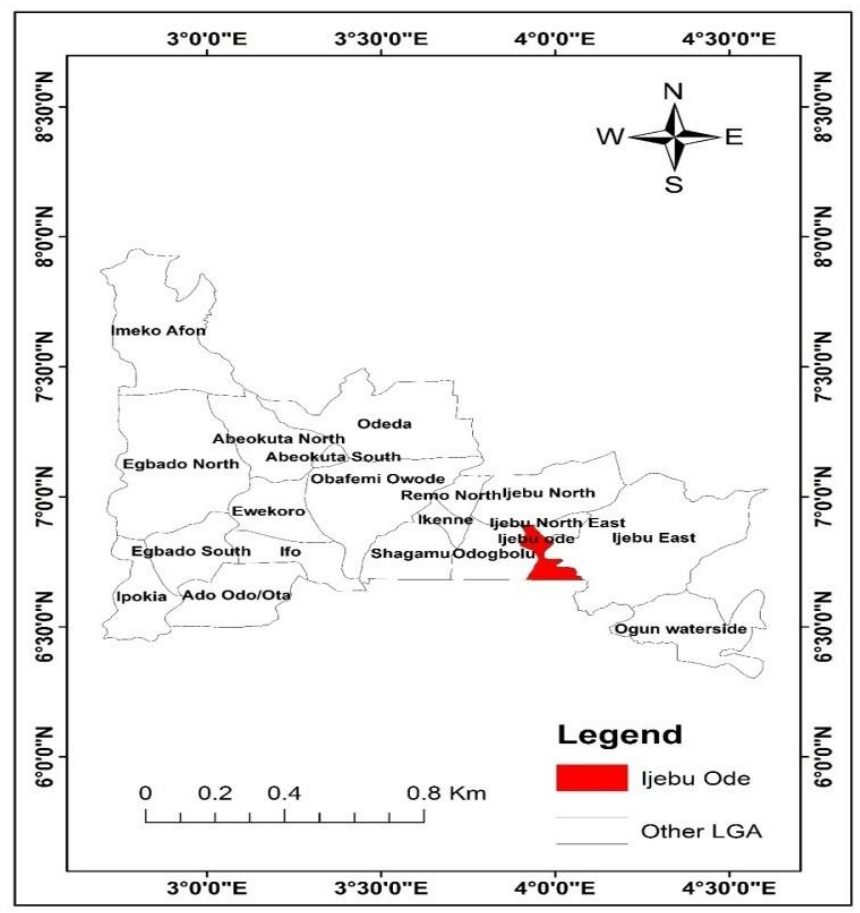

Figure 1. Map of Ogun State showing Ijebu Ode

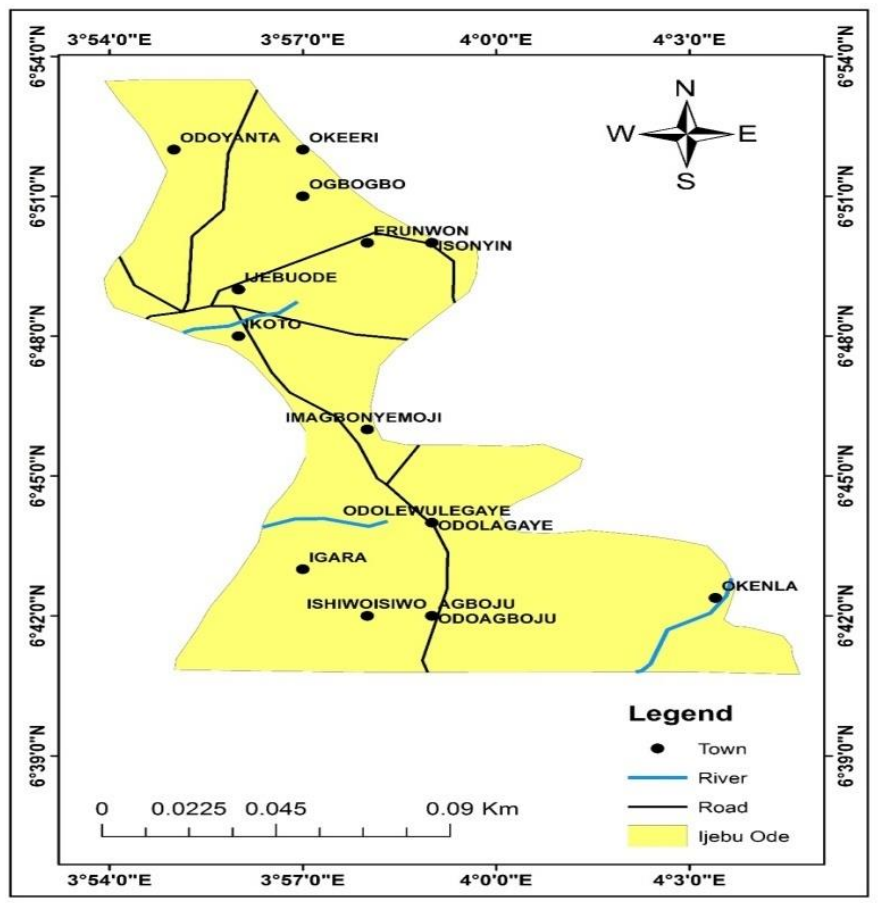

Figure 2. Map of Ijebu Ode 
E.A. Adeleke and E.A. Orebayo et al / GEOSI Vol 5 No 2 (2020) 226-249

The vegetation of the area is of the tropical rainforest vegetation of Nigeria. In terms of vegetation, the state can be divided into three distinctive zones. Where the state shares a boundary with the Atlantic Ocean, the vegetation is of a swampy type with mangroves and other edaphic trees. about $400 \mathrm{~km}^{2}$ is of basement complex rocks of preCambrian formation. The whole state is drained by flowing coastal rivers such as Ogun, Yewa, and Shasha from Oyo state through the thickly vegetated western part of the state. Numerous small rivers and streams are at the south eastern parts flowing perennially through the swampy terrain.

According to the National population commission (2006 census), ijebu-Ode local government area has a population of 154,032, and an estimated population of 222,653 (2007). The State has enormous industrial potentials. There are also other modern industries producing high quality beer, bicycle tyres, ceramic goods, high quality clay bricks, carpet and clothing materials (Onakomaiya, 2000). The data required for the study include Mean and annual temperature, rainfall and sunshine hours between 1983-2017. These data were collected from the Nigeria Meteorological Agency (NIMET) at the headquarters in Oshodi Lagos state while the map of Ijebu ode was extracted from the administrative map of Nigeria using Arc GIS 10.3 software. Onset of the rainy season will be compiled using Walter (1967) formula because of its higher reliability in predicting the onset of the rains among different methods. The formula is expressed in equation 1.

Onset $=\underline{\mathrm{DM}}(51-\mathrm{A})$

TM

Where DM = number of days of the month containing the onset of rainfall, $\mathrm{A}=$ Total rainfall for the previous month, $\mathrm{TM}=$ total rainfall for the month in which $51 \mathrm{~mm}$ or more is reached.

The cessation of rainy season is defined as the last occasion of rainfall that record rainfall of $51 \mathrm{~mm}$ and above. Cessation of the rainy season will be compiled using Walter 
(1967) formula because of its higher reliability in predicting the onset of the rains among different methods. The formula is expressed in equation 2 .

Cessation $=\underline{\mathrm{DM}(51-\mathrm{A})}$

TM

Where $\mathrm{DM}=$ number of days of the month containing the cessation of rainfall, $\mathrm{A}=$ Total rainfall for the previous month, $\mathrm{TM}=$ total rainfall for the month in which $51 \mathrm{~mm}$ or more is reached. Therefore, the length of the rainy season is the total number of days between the Onset and Cessation date.

The Anomaly Index expresses the degree of rainfall and temperature anomaly for the relevant periods in relation to the long term mean rainfall and temperature for the study period. To calculate the rainfall and temperature anomaly for the study period, standardize rainfall anomaly index (SAI) will be used. The formula is given in equation 3.

$\mathrm{SAI}=\frac{X-\bar{X}}{S D}$

Where $\mathrm{x}=$ mean annual rainfall or temperature, $\bar{X}=$ mean of entire series, $\mathrm{SD}=$ Standard deviation of the entire series. Correlation will be used to measure the relationship between the rainfall and temperature for the study period.

$\mathfrak{r}=\frac{n(\Sigma x y)-(\Sigma x)(\Sigma y)}{\sqrt{\left[n \Sigma x^{2}-(\Sigma x)^{2}\right]\left[n \Sigma y^{2}-(\Sigma y)^{2}\right]}}$

Where, $y=$ temperature, and $x=$ rainfall.

$\mathrm{T}$ test was used to ascertain whether there is a significant difference between onset dates, cessation dates and length of rainy season in the area. Time series is defined as a series of observation assumed by a variable over successive time periods. Time series analysis helps to fit an array of time bound data on a line of best fit, it helps to show the type of trends existing in the data graphically. Time series will be used to examine the trends of rainfall and temperature for the study period and for predict for the future years. The trend line equation of a time series data is as shown in equation 5 . 
$\mathrm{Y}=\mathrm{A}+\mathrm{B}(\mathrm{X})$

Where, $\mathrm{A}=$ intercept, $\mathrm{B}=$ rate of change per time, and $\mathrm{X}=$ coded values of years.

\section{Results and Discussion}

3.1 Descriptive Statistics of Onset, Cessation and Length of Rainy Season

Table 1 presents the onset dates, cessation dates and length of rainy season in the area for the study period. During the study period, rainfall started lately in 1983, rainy season started on $16^{\text {th }}$ April $\left(106^{\text {th }}\right.$ day of the year) while it started earliest in 2004 , rainy season started on February $3^{\text {rd }}$ ( $34^{\text {th }}$ day of the year). The mean onset date of rain in the area during the study period is $13^{\text {th }}$ March ( $72^{\text {nd }}$ day of the year) with a standard deviation of 18.8 and a coefficient of variation of $25.7 \%$, this implies that onset date during the study period is heterogeneous. Furthermore, rainy season started in February in 1982, 1986, 1987, 1991, 1993, 1996, 1999, 2003, 2004 and 2011 respectively, it started in March in 1981, 1984, 1985, 1988, 1989, 1994, 1995, 1997, 2000, 2002, 2005, 2006, 2012, 2013, 2014, 2015 and 2016 respectively while it started in April in 1983, 1990, 1998, 2001, 2007, 2008, 2009, 2010 and 2017. This result shows that rainfall starts within the month of February to April in the study period. Also, during the study period, $27 \%$ of the onset dates was in February, $46 \%$ in March while $27 \%$ was in the month of April.

In Table 1, the earliest cessation date of the rainy season in the area was in 1983 which occurred on September $22^{\text {nd }}\left(265^{\text {st }}\right.$ day of the year) while the latest cessation date was in 1990 which occurred in the $10^{\text {th }}$ of December ( $344^{\text {st }}$ day of the year). The mean cessation date of the rainy season in the area during the study period is October $23^{\text {rd }}$ (296 ${ }^{\text {th }}$ day of the year) with a standard deviation of 15.8 and a coefficient of variation of 5.3\%. This implies that cessation dates during the study period was homogeneous. Also, Cessation dates in 1982, 1983, 1985, 1986, 1987, 1989, 1991, 1993, 1995, 1996, 2000, 2001, 2003, 2004, 2005, 2006 and 2008 are lower than the mean value of $23^{\text {rd }}$ October while cessation dates in 1981, 1984, 1988, 1990, 1997, 1999. 2007, 2009, 2010, 2011, 
E.A. Adeleke and E.A. Orebayo et al / GEOSI Vol 5 No 2 (2020) 226-249

2012, 2013, 2014, 2015, 2016 and 2017 are higher than the mean value and cessation dates in 1992, 1994 and 1998 are the same dates with the mean value of $23^{\text {rd }}$ October.

Table 1. Onset, cessation and length of rainy season

\begin{tabular}{|c|c|c|c|c|c|}
\hline Year & Onset Date & Julian Day & Cessation Date & Julian Day & Length of Rainy Season \\
\hline 1981 & $15^{\text {th }}$ March & $74^{\text {th }}$ day & $1^{\text {st }}$ November & $305^{\text {th }}$ & 231 \\
\hline 1982 & $25^{\text {th }}$ February & $56^{\text {th }}$ day & $17^{\text {th }}$ October & $290^{\text {th }}$ & 234 \\
\hline 1983 & $16^{\text {th }}$ April & $106^{\text {th }}$ day & $22^{\text {nd }}$ September & $265^{\text {th }}$ & 159 \\
\hline 1984 & $8^{\text {th }}$ March & $68^{\text {th }}$ day & $23^{\text {rd }}$ October & $297^{\text {th }}$ & 229 \\
\hline 1985 & $20^{\text {th }}$ March & $79^{\text {th }}$ day & $21^{\text {st }}$ October & $294^{\text {th }}$ & 215 \\
\hline 1986 & $27^{\text {th }}$ February & $58^{\text {th }}$ day & $11^{\text {th }}$ October & $284^{\text {th }}$ & 226 \\
\hline 1987 & $14^{\text {th }}$ February & $45^{\text {th }}$ day & $19^{\text {th }}$ October & $292^{\text {nd }}$ & 247 \\
\hline 1988 & $6^{\text {th }}$ March & $66^{\text {th }}$ day & $26^{\text {th }}$ October & $300^{\text {th }}$ & 234 \\
\hline 1989 & $9^{\text {th }}$ March & $68^{\text {th }}$ day & $22^{\text {nd }}$ October & $295^{\text {th }}$ & 227 \\
\hline 1990 & $11^{\text {th }}$ April & $101^{\text {st }}$ day & $10^{\text {th }}$ December & $344^{\text {th }}$ & 243 \\
\hline 1991 & $23^{\text {rd }}$ February & $54^{\text {th }}$ day & $19^{\text {th }}$ October & $292^{\text {nd }}$ & 238 \\
\hline 1992 & $9^{\text {th }}$ April & $100^{\text {th }}$ day & $22^{\text {nd }}$ October & $296^{\text {th }}$ & 196 \\
\hline 1993 & $21^{\text {st }}$ February & $52^{\text {nd }}$ day & $20^{\text {th }}$ October & $293^{\mathrm{rd}}$ & 241 \\
\hline 1994 & $15^{\text {th }}$ March & $74^{\text {th }}$ day & $23^{\text {rd }}$ October & $296^{\text {th }}$ & 222 \\
\hline 1995 & $10^{\text {th }}$ March & $69^{\text {th }}$ day & $20^{\text {th }}$ October & $293^{\text {rd }}$ & 224 \\
\hline 1996 & $17^{\text {th }}$ February & $48^{\text {th }}$ day & $18^{\text {th }}$ October & $292^{\text {nd }}$ & 244 \\
\hline 1997 & $23^{\text {rd }}$ March & $82^{\text {nd }}$ day & $9^{\text {th }}$ December & $343^{\text {rd }}$ & 261 \\
\hline 1998 & $14^{\text {th }}$ April & $104^{\text {th }}$ day & $23^{\text {rd }}$ October & $296^{\text {th }}$ & 192 \\
\hline 1999 & $26^{\text {th }}$ February & $57^{\text {th }}$ day & $26^{\text {th }}$ October & $299^{\text {th }}$ & 242 \\
\hline 2000 & $21^{\text {st }}$ March & $52^{\text {nd }}$ day & $15^{\text {th }}$ October & $289^{\text {th }}$ & 237 \\
\hline 2001 & $4^{\text {th }}$ April & $94^{\text {th }}$ day & $26^{\text {th }}$ September & $269^{\text {th }}$ & 175 \\
\hline 2002 & $29^{\text {th }}$ March & $88^{\text {th }}$ day & $24^{\text {th }}$ October & $297^{\text {th }}$ & 209 \\
\hline 2003 & $25^{\text {th }}$ February & $56^{\text {th }}$ day & $17^{\text {th }}$ October & $290^{\text {th }}$ & 234 \\
\hline 2004 & $3^{\text {rd }}$ February & $34^{\text {th }}$ day & $23^{\text {rd }}$ September & $267^{\text {th }}$ & 233 \\
\hline 2005 & $13^{\text {th }}$ March & $72^{\text {nd }}$ day & $28^{\text {th }}$ September & $271^{\text {st }}$ & 199 \\
\hline 2006 & $7^{\text {th }}$ March & $66^{\text {th }}$ day & $20^{\text {th }}$ October & $293^{\text {rd }}$ & 227 \\
\hline 2007 & $1^{\text {st }}$ April & $91^{\text {st }}$ day & $29^{\text {th }}$ October & $302^{\text {nd }}$ & 211 \\
\hline 2008 & $9^{\text {th }}$ April & $100^{\text {th }}$ day & $20^{\text {th }}$ October & $294^{\text {th }}$ & 194 \\
\hline 2009 & $2^{\text {nd }}$ April & $92^{\text {nd }}$ day & $13^{\text {th }}$ November & $317^{\text {th }}$ & 225 \\
\hline 2010 & $11^{\text {th }}$ April & $101^{\text {st }}$ day & $11^{\text {th }}$ November & $315^{\text {th }}$ & 214 \\
\hline 2011 & $21^{\text {st }}$ February & $52^{\text {nd }}$ day & $26^{\text {th }}$ October & $299^{\text {th }}$ & 247 \\
\hline 2012 & $13^{\text {th }}$ March & $73^{\text {rd }}$ day & $26^{\text {th }}$ October & $300^{\text {th }}$ & 227 \\
\hline 2013 & $6^{\text {th }}$ March & $65^{\text {th }}$ day & $26^{\text {th }}$ October & $299^{\text {th }}$ & 234 \\
\hline 2014 & $11^{\text {th }}$ March & $70^{\text {th }}$ day & $26^{\text {th }}$ October & $299^{\text {th }}$ & 229 \\
\hline 2015 & $15^{\text {th }}$ March & $74^{\text {th }}$ day & $25^{\text {th }}$ October & $298^{\text {th }}$ & 224 \\
\hline 2016 & $12^{\text {th }}$ March & $72^{\text {nd }}$ day & $30^{\text {th }}$ October & $304^{\text {th }}$ & 232 \\
\hline 2017 & $3^{\text {rd }}$ April & $93^{\text {rd }}$ day & $27^{\text {th }}$ October & $300^{\text {th }}$ & 207 \\
\hline Mean & $13^{\text {th }}$ March & $73^{\text {nd }}$ day & $23^{\text {rd }}$ October & $296^{\text {th }}$ day & 223 \\
\hline STD & & 18.8 & & 15.8 & 20.8 \\
\hline CV (\%) & & 25.7 & & 5.3 & 9.3 \\
\hline
\end{tabular}

Note $: \mathrm{CV}=$ Climatic Variable, $\mathrm{STD}=$ Standard Deviation 
E.A. Adeleke and E.A. Orebayo et al / GEOSI Vol 5 No 2 (2020) 226-249

As shown in Table 1, the lowest length of rainy season of 159 days was recorded in 1983 while the highest of 261 days was recorded in 1997. The mean length of rainy season in the area is 223 days with a standard deviation of 20.8 and a coefficient of variation of $9.3 \%$. This implies that the length of rainy season in the area is homogeneous. Furthermore, length of rainy season in 1983, 1985, 1992, 1994, 1998, 2001, 2002, 2005, 2007, 2008, 2010 and 2017 are lower than the mean value of 223 days while length of rainy season in 1981, 1982, 1984, 1986, 1987, 1988, 1989, 1990, 1991, 1993, 1995, 1996, 1997, 1999, 2000, 2003, 2004, 2006, 2009. 2011, 2012, 2013, 2014 , 2015 and 2016 are higher than the mean value of 223 days.

\subsection{Pattern of Onset Dates}

Figure 3 presents the pattern of Onset date of rainy season in the area during the study period. The trend of onset date is upward sloping, this implies that rainfall is starting late in the study period. The trend also shows that the latest date of onset was in 1983 while the earliest date was in 2004. This result implies that onset dates in the area is affected by climate change, rain now starts late in the study area.

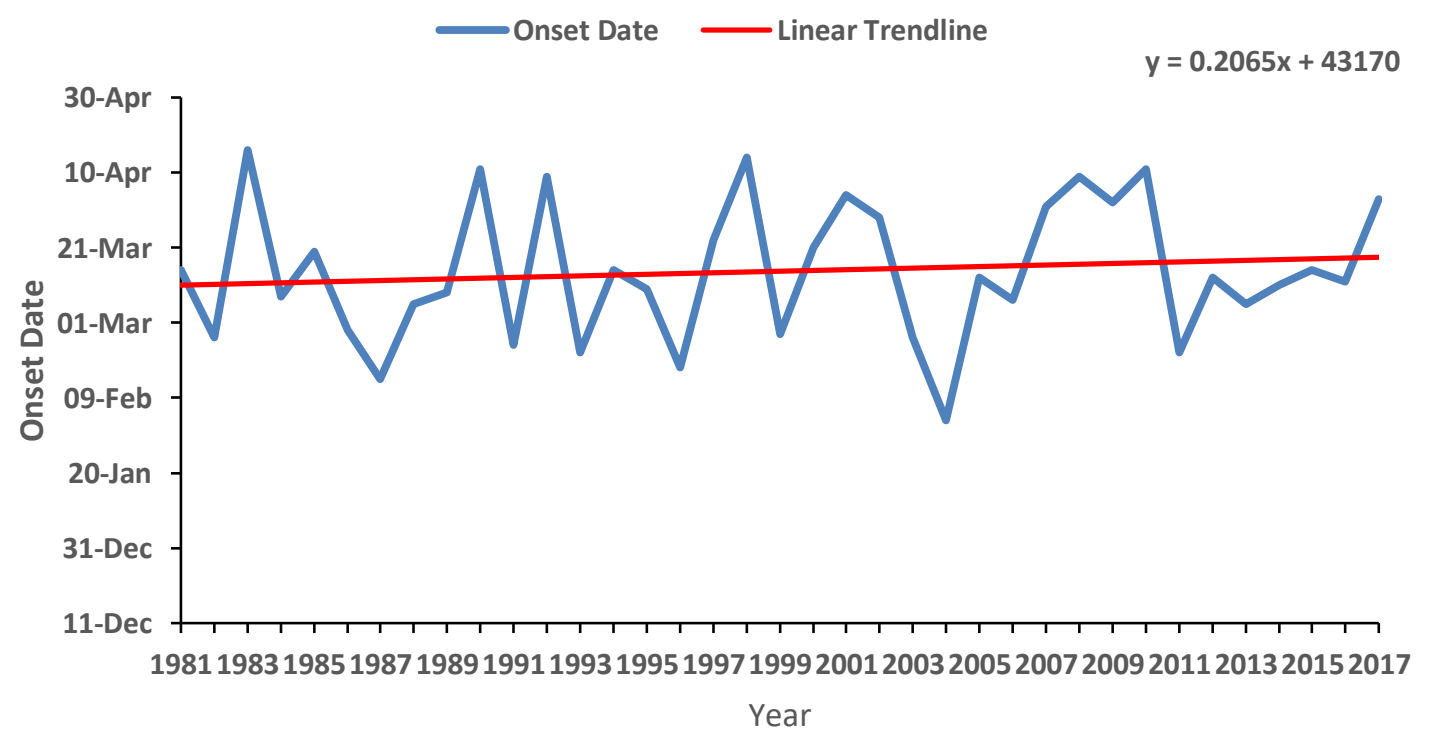

Figure 3. Pattern of Onset Dates 
E.A. Adeleke and E.A. Orebayo et al / GEOSI Vol 5 No 2 (2020) 226-249

\subsection{Pattern of Cessation Dates}

As shown in Figure 4, the trend of cessation dates in the area is upward sloping, this implies that cessation dates in the study area is getting late. Furthermore, the earliest cessation date was in 1983 while the latest was in 1990. Also, the trend shows that cessation dates where early between 1981 to 1996 and late between 1997 and 2017. This result shows that climate change has led to late cessation of rainfall in the area.

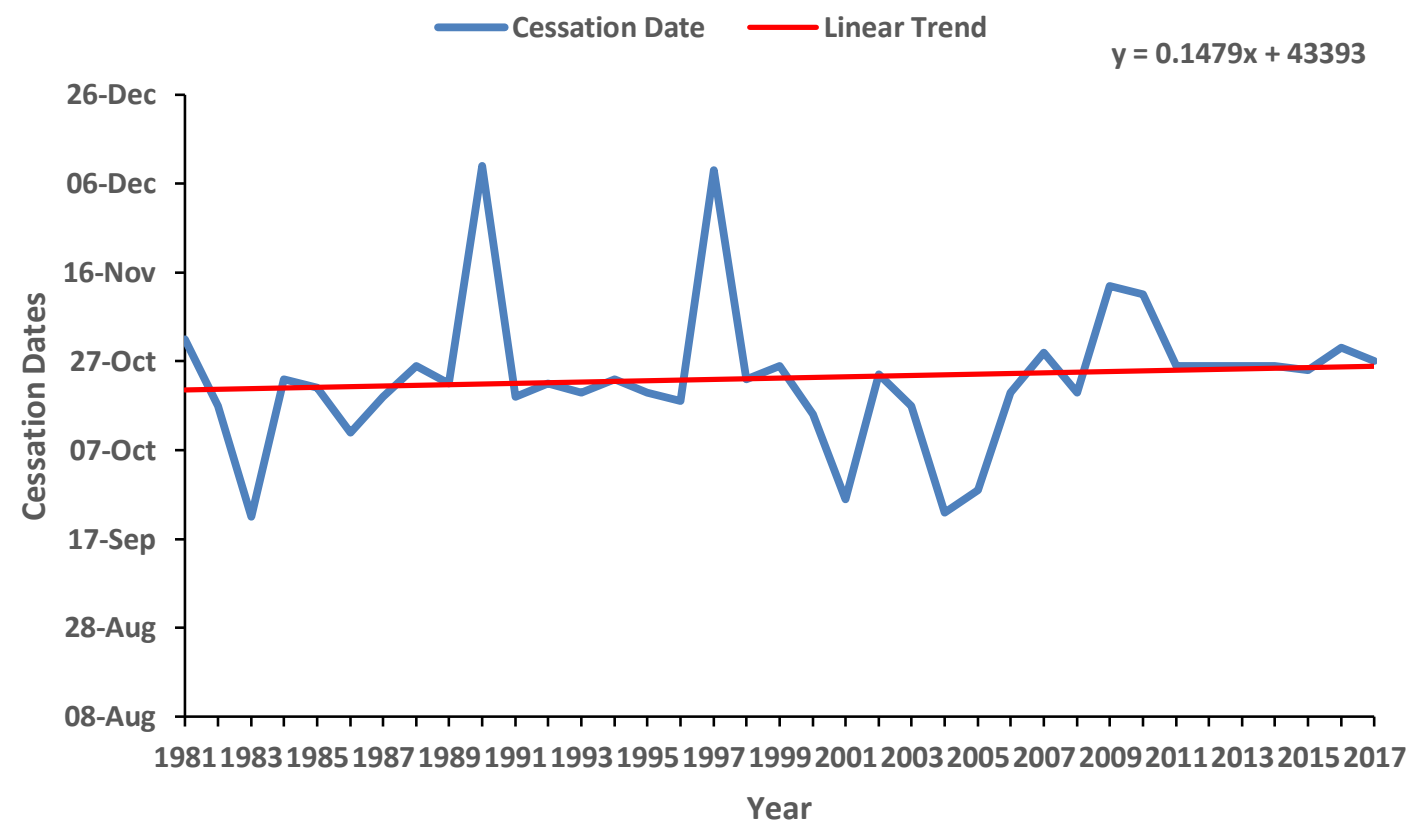

Figure 4. Pattern of Cessation Dates

\subsection{Pattern of Length of Rainy Season}

As shown in Figure 5, the trend of length of rainy season is downward sloping, this implies that there is a decreased in the length of rain season in the area. Also the result of the trend line equation $y=-0.0512 x+224.3$ is negative, meaning that the area has been experiencing a significant decrease in length of rainy season over the period of 35 years. This further shows a predicted rate of decrease of about -0.0512 per annum. The 
E.A. Adeleke and E.A. Orebayo et al / GEOSI Vol 5 No 2 (2020) 226-249

decrease in the length of rainy season is as a result of late onset of rainfall and early cessation.

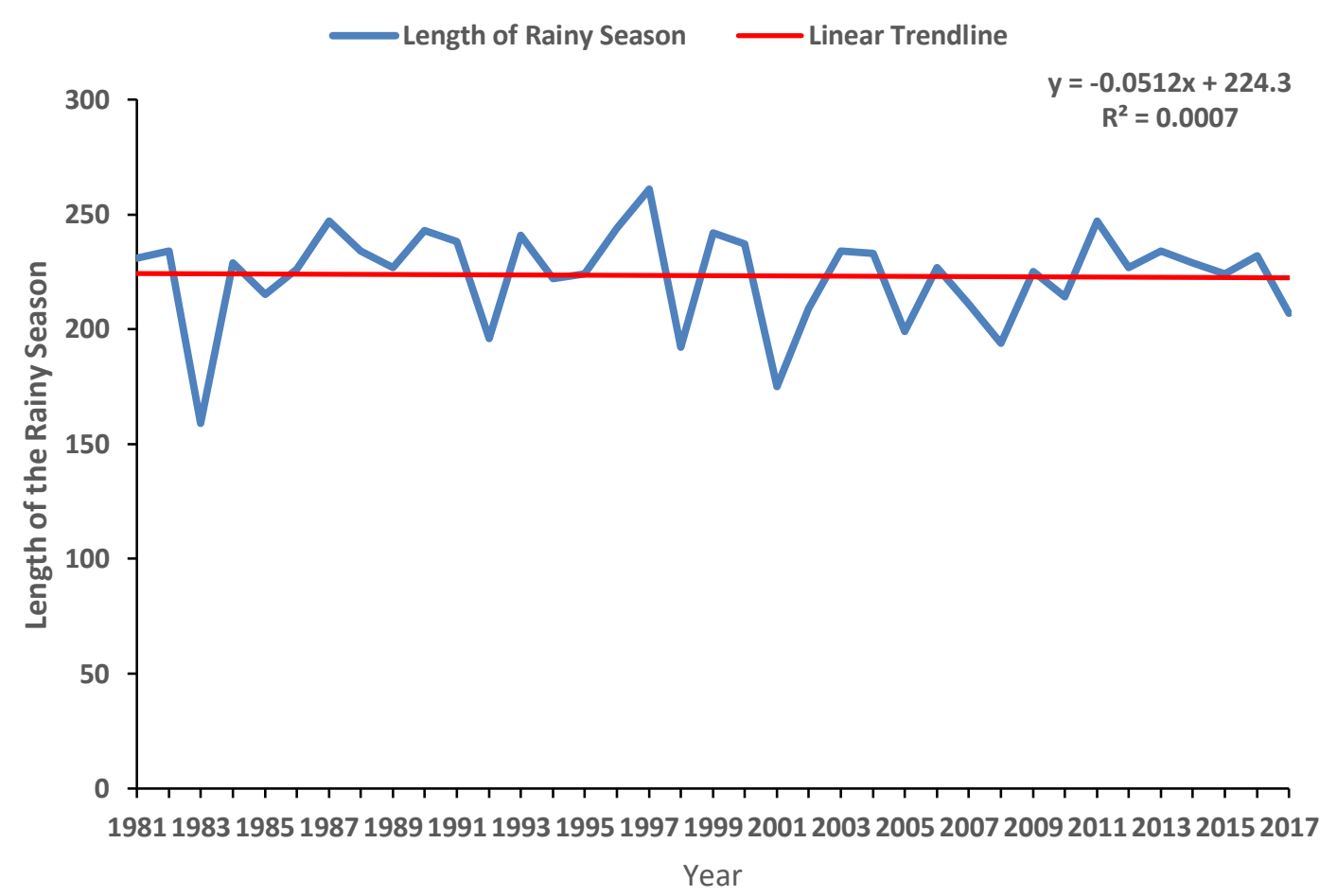

Figure 5. Length of Rainy Season

\subsection{Anomalous Rainfall And Temperature}

Table 2 presents the years with anomalous rainfall in the study area during the study period. 1994 experienced the driest year with an anomaly index of -2.12 while 2011 experienced the wettest year with an anomaly index of 2.28. Furthermore, 1985 recorded the coldest year with a temperature anomaly index of -2.31 while 2006 recorded the hottest year with a temperature anomaly index of 1.73 . 
E.A. Adeleke and E.A. Orebayo et al / GEOSI Vol 5 No 2 (2020) 226-249

Table 2. Anomalous rainfall and temperature

\begin{tabular}{|c|c|c|}
\hline Year & Anomalous Rainfall & Anomalous Temperature \\
\hline 1981 & 0.92 & -0.38 \\
\hline 1982 & -1.66 & -1.15 \\
\hline 1983 & -1.47 & -0.38 \\
\hline 1984 & -0.67 & 0 \\
\hline 1985 & 0.03 & -2.31 \\
\hline 1986 & -1.82 & -1.35 \\
\hline 1987 & 0.82 & 1.35 \\
\hline 1988 & 1.08 & 0 \\
\hline 1989 & 0.81 & -0.58 \\
\hline 1990 & -0.69 & 1.35 \\
\hline 1991 & -0.47 & 0 \\
\hline 1992 & -0.46 & -0.38 \\
\hline 1993 & -0.39 & 0.19 \\
\hline 1994 & -2.12 & 0 \\
\hline 1995 & -0.45 & 0.96 \\
\hline 1996 & 1.09 & 0.58 \\
\hline 1997 & 0.63 & 0.01 \\
\hline 1998 & -0.30 & 0.03 \\
\hline 1999 & 1.92 & 0 \\
\hline 2000 & 0.03 & 0.38 \\
\hline 2001 & -1.35 & 0.58 \\
\hline 2002 & 0.23 & 0.58 \\
\hline 2003 & -0.32 & 0.77 \\
\hline 2004 & -0.16 & 0.58 \\
\hline 2005 & -1.39 & -0.19 \\
\hline 2006 & -0.50 & 1.73 \\
\hline 2007 & 1.12 & -1.73 \\
\hline 2008 & 0.38 & -0.77 \\
\hline 2009 & 0.61 & -1.92 \\
\hline 2010 & 1.00 & -1.92 \\
\hline 2011 & 2.28 & -0.19 \\
\hline 2012 & 0.26 & 0.19 \\
\hline 2013 & 0.46 & 0 \\
\hline 2014 & 0.51 & 0.19 \\
\hline 2015 & 0.02 & 1.35 \\
\hline 2016 & 0.32 & 0.58 \\
\hline 2017 & -0.29 & 1.35 \\
\hline
\end{tabular}

In Figure 6, 1982, 1983, 1984, 1986, 1990, 1991, 1992, 1993, 1994, 1995, 1998, 2001, 2003, 2004, 2005, 2006 and 2017 experienced negative anomaly, this implies that these years are dry experiencing rainfall below the normal while 1981, 1985, 1987, 1988, 1989, 1996, 1997, 1999, 2000, 2002, 2007, 2008, 2009, 2010, 2012, 2013, 2014, 2015 
E.A. Adeleke and E.A. Orebayo et al / GEOSI Vol 5 No 2 (2020) 226-249

and 2016 experienced positive anomaly, rainfall received in this years are above the normal.

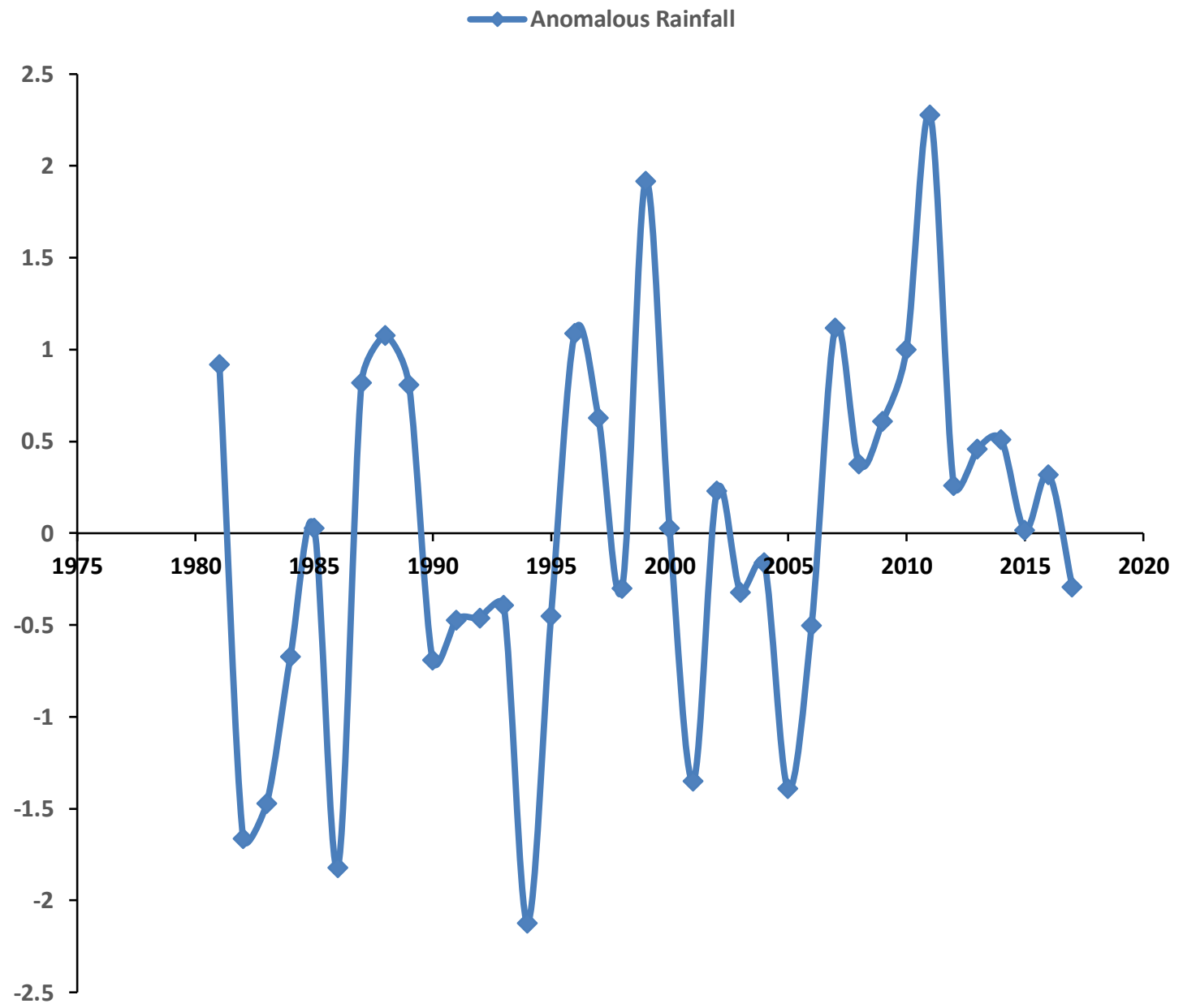

Figure 6. Anomalous rainfall

Figure 7 presents the graph of temperature anomaly in the area for the study period. Temperature recorded in 1981, 1982, 1983, 1985, 1986, 1989, 1992, 2005, 2007, 2008, 2009, 2010 and 2011 showed a negative anomaly while 1987, 1990, 1993, 1995, 1996, 1997, 1998, 2000, 2001, 2002, 2003, 2004, 2012, 2014, 2015 and 2016 showed a negative anomaly. Also, 1984, 1988, 1994, 1999 and 2013 experienced a normal temperature for the study area. 
E.A. Adeleke and E.A. Orebayo et al / GEOSI Vol 5 No 2 (2020) 226-249

Anomalous Temperature

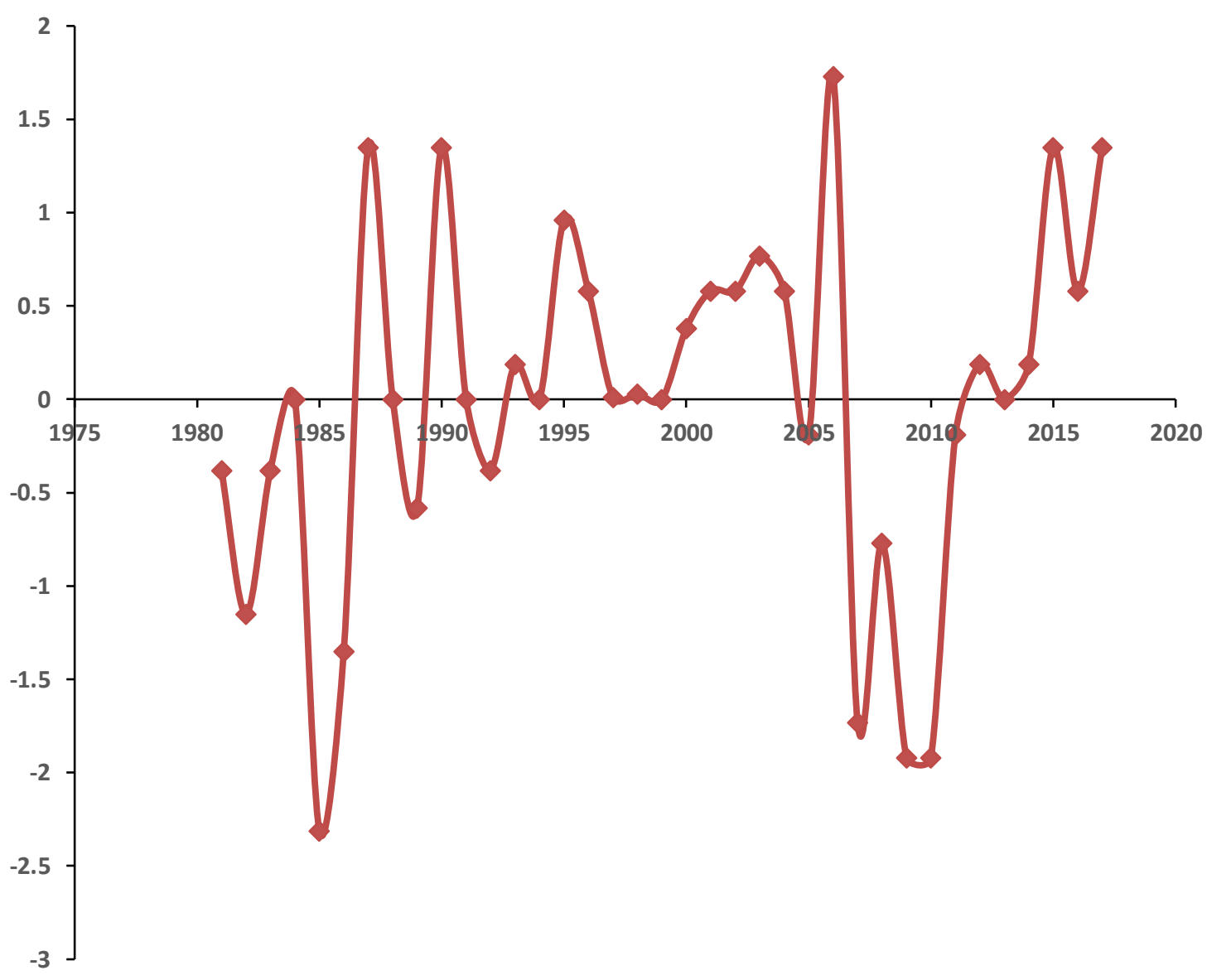

Figure 7. Anomalous temperature

3.6 Relationship Between Rainfall and Temperature

Table 3 presents the correlation coefficients between rainfall and temperature in the study area. The Minimum temperature $(r=0.084)$, sunshine hours $(r=0.220)$, cessation $(r=0.641)$ and Length of rainy season $(0.406)$ are positive. This implies that minimum temperature, sunshine hours, cessation and length of rainy season are directly related to rainfall amount. However, if minimum temperature, sunshine hours, cessation 
and length of rainy season increases, rainfall increases and if minimum temperature, sunshine hours, cessation and length of rainy season decreases, rainfall decreases. Furthermore, the Maximum temperature $(r=-0.191)$, average temperature $(r=-0.044)$ and Onset $(\mathrm{r}=-0.119)$ are negative; this implies that maximum temperature, average temperature and onset are inversely related to rainfall amount. If maximum temperature, average temperature and onset increases, rainfall decreases and if maximum temperature, average temperature and onset decreases, rainfall increases. The implication of this maximum temperature and average temperature influences rainfall in the area.

As indicated in Table 3, the correlation coefficient of maximum temperature (0.325), sunshine hours (0.380), average temperature (0.867), cessation and length of rainy season $(0.080)$ is positive. This means that there is a directly relationship between minimum temperature and maximum temperature, sunshine hours' average temperature and length of rainy season. However, implies that if these variables increase, minimum temperature will increase and if these variables decrease, minimum temperature will decrease. Also, Onset (-0.118) and cessation (-0.026) is negative; this implies that there is an inverse relationship between onset date, cessation date and minimum temperature.

Table 3. Relationship between the climatic variables

\begin{tabular}{ccccccccc}
\hline Variable & Rainfall & $\begin{array}{c}\text { Min. } \\
\text { Temp }\end{array}$ & $\begin{array}{c}\text { Max. } \\
\text { Temp }\end{array}$ & Sunshine & $\begin{array}{c}\text { Average } \\
\text { Temp. }\end{array}$ & Onset & Cessation & LRS \\
\hline Rainfall & 1 & & & & & & & \\
Min T. & 0.080 & 1 & & & & & & \\
Max T. & -0.191 & $0.325^{*}$ & 1 & & & & & \\
Sunshine & 0.220 & $0.380^{*}$ & $-0.389^{*}$ & 1 & & & & \\
Average & -0.044 & $0.867^{*}$ & $0.749^{*}$ & 0.069 & 1 & & & \\
T. & & & & & & \\
Onset & -0.119 & -0.118 & -0.203 & -0.141 & -0.191 & 1 & & \\
Cessation & $0.408^{*}$ & -0.026 & -0.031 & 0.079 & -0.031 & 0.318 & 1 & \\
LRS & $0.406^{*}$ & 0.080 & 0.131 & 0.101 & 0.131 & $-0.642^{*}$ & $0.509^{*}$ & 1 \\
\hline
\end{tabular}

Note $:$ LRS $=$ Length of rainy season, Temp./T. $=$ temperature

Furthermore, the correlation coefficient Average temperature $(r=0.749)$ and Length of rainy season $(r=0.131)$ is positive, this implies that there is a direct relationship between average temperature, length of rainy season and maximum 
E.A. Adeleke and E.A. Orebayo et al / GEOSI Vol 5 No 2 (2020) 226-249

temperature. Also, sunshine hours $(r=-0.389)$, onset $(r=-0.203)$ and cessation $(r=-$ 0.031) is negative, this implies that there is an inverse relationship between sunshine hours, onset, cessation and maximum temperature.

In the same vein, the correlation coefficient average temperature $(r=0.069)$, cessation $(r=0.079)$ and length of rainy season $(r=0.201)$ is positive, meaning that there is a direct relationship between average temperature, cessation, length of rainy season and sunshine hours. Further, onset $(-0.141)$ is negative; this implies that there is an inverse relationship between onset and sunshine hours. Also, the correlation coefficient length of rainy season (0.189) is positive; this implies that there is a direct relationship between length of rainy season and average temperature while onset (-0.191) and cessation (0.031) is negative, this implies that there is an inverse relationship between onset, cessation and average temperature. Furthermore, the correlation coefficient, Length of rainy season (-0.642) is negative, this implies that there is an inverse relationship between length of rainy season and Onset. While onset (-0.642) is inversely related to length of rainy season. In the same vein, cessation (0.509) is directly related to length of rainy season.

Furthermore, cessation $\left(0.408^{*}\right)$ and length of rainy season $\left(0.406^{*}\right)$ are significantly related to rainfall, Minimum temperature $\left(0.325^{*}\right)$, sunshine hours $\left(0.380^{*}\right)$ and average temperature $\left(0.867^{*}\right)$ is significantly related to minimum temperature. In the same vein, sunshine hours $\left(-0.389^{*}\right)$ and average temperature $\left(0.749^{*}\right)$ are significantly related to maximum temperature. Also, Onset $\left(-0.642^{*}\right)$ and cessation $\left(0.509^{*}\right)$ are significantly related to length of rainy season.

\subsection{Significant Difference Between Climatic Variables}

Table 4 presents the result of student $t$ test to determine if there is significant difference in Onset dates, cessation dates and length of rainy season. since calculated t (23.539) is greater than p-value (2.028) for onset; we reject the null hypothesis and accept 
E.A. Adeleke and E.A. Orebayo et al / GEOSI Vol 5 No 2 (2020) 226-249

the alternative hypothesis which states that there is a significant difference in onset dates in the study area.

Table 4. T Test at 0.05 significant level

\begin{tabular}{|c|c|c|c|c|c|c|}
\hline & \multicolumn{6}{|c|}{ Test Value $=0.95$} \\
\hline & \multirow[t]{2}{*}{$\mathrm{T}$} & \multirow[t]{2}{*}{ Df } & \multirow[t]{2}{*}{ Sig. } & \multirow{2}{*}{$\begin{array}{c}\text { Mean } \\
\text { Difference }\end{array}$} & \multicolumn{2}{|c|}{$\begin{array}{l}\text { 95\% Confidence Interval of the } \\
\text { Difference }\end{array}$} \\
\hline & & & & & Lower & Upper \\
\hline Onset & 23.539 & 36 & 2.028 & 73.13514 & 66.8339 & 79.4364 \\
\hline Cessation & 113.527 & 36 & 2.028 & 296.45946 & 291.1634 & 301.7555 \\
\hline LRS & 65.148 & 36 & 2.028 & 223.32432 & 216.3721 & 230.2765 \\
\hline
\end{tabular}

Note : LRS $=$ Length of rainy season

In the same vein, since calculated $\mathrm{T}$ (113.527) is greater than p-value (2.028) for cessation, thus, we reject the null hypothesis and accept the alternative hypothesis which states that there is a significant difference in cessation dates in the study area. Furthermore, since calculated T (65.148) is greater than p-value (2.028) for length of the rainy season, we reject the null hypothesis and accept the alternative hypothesis which states that there is a significant difference in length of rainy season in the study area. This result implies that onset dates in the area is affected by climate change, rain now starts late in the study area. These results are similar to those reported by Zhang \& Fueglistaler (2019) that changes in the atmospheric circulation pattern can enhance rainfall in one place and suppress rainfall in another. Climate change also has led to late cessation of rainfall in the area. These results are similar to those reported by (Bae et al., 2019) that by the occurrence of all different types of droughts is associated with extreme meteorological droughts, which are mainly caused by precipitation deficits in the wet season or prolonged rainfall shortages. These results are supported by Yacoub \& Tayfur (2020) that there is pronounced decrease in precipitation at the southern region, reaching to almost a total of $300 \mathrm{~mm}$ deficit innearly 100-year period. 
E.A. Adeleke and E.A. Orebayo et al / GEOSI Vol 5 No 2 (2020) 226-249

The trend of length of rainy season is downward sloping, this implies that there is a decreased in the length of rain season in the area. These results were different from those of Zhang \& Zhou (2019), who reported that for the global monsoon region as a whole, significant increases in extreme precipitation and associations with global warming are also identified, however with limited spatial coverage. The years with anomalous rainfall in the study area during the study period. These results are similar to those reported by Olaniyan et al. (2019) that the Intertropical Discontinuity (ITD) and the Sea Surface Temperature (SST) over the Central Pacific, exhibit direct teleconnection with the onset anomaly. These results are supported by Fitzpatrick et al. (2019) that a potential use of local onset regions are presented that shows the link between the annual intertropical front progression and local agronomic onset. If maximum temperature, average temperature and onset increases, rainfall decreases and if maximum temperature, average temperature and onset decreases, rainfall increases. These results are similar to those reported by Sharma et al. (2018) that the increase in frequency and magnitude of extreme rainfall has been attributed to the increasing trend in maximum and minimum temperature. These results are supported by Meshram et al. (2018) that the monsoon and the winter season exhibited a negative trend in rainfall changes over the period of study.

\section{Conclusion}

The area is experiencing a significant increase in minimum temperature, sunshine hours, rainfall and average temperature while it is experiencing a significant decrease in maximum temperature. However, rains start early in the area and ceases late, resulting to a prolonged length of rainy season because the area is experiencing a decline in the length of rainy season. It could also be noted that onset dates of rains and cessation dates are major determinants of length of rainy season as a change in any of the two variables will affect the length of the rainy season. The rainfall anomaly over all the area revealed that there was a composite nature in which. Early warning systems about extreme 
temperature and rainfall events should be put in place. This will help reduce the cost of destruction caused by this extreme weather events especially in the case of flood. Early warning about temperature events can help prevent disease such as meningitis that is related with temperature. The response should involve flood forecasting and early warning using rainfall data, rescue and evacuation and post flood impact assessment, recovery and rehabilitation.

\section{Conflict of Interest}

The authors declare that there is no conflict of interest with any financial, personal, or other relationships with other people or organizations related to the material discussed in the article.

\section{References}

Abatan, A. A., Abiodun, B. J., Adefisan, E. A., \& Gutowski, W. J., Jr. (2019). Hot days and tropical nights in nigeria: Trends and associated large-scale features. Theoretical and Applied Climatology, 137(3-4), 2077-2093. doi:10.1007/s00704-018-2713-0.

Abatan, A. A., Abiodun, B. J., Lawalc, K. A., \& Gutowski, W. J., Jr. (2016). Trends in extreme temperature over nigeria from percentile-based threshold indices. International Journal of Climatology, 36(6), 2527-2540. doi: $10.1002 /$ joc. 4510 .

Ahokpossi, Y. (2018). Analysis of the rainfall variability and change in the republic of benin (west africa). Hydrological Sciences Journal, 63(15-16), 2097-2123. doi:10.1080/02626667.2018.1554286.

Aiyelokun, O., \& Odekoya, O. (2016). Analysis of trend and variability of atmospheric temperature in Ijebu-Ode, Southwest Nigeria. International Research Journal of Agriculture Science, 6(2), 025-031.

Akinbile, C. O., Ogunmola, O. O., Abolude, A. T., \& Akande, S. O. (2020). Trends and spatial analysis of temperature and rainfall patterns on rice yields in nigeria. Atmospheric Science Letters, 21(3) doi:10.1002/asl.944. 
E.A. Adeleke and E.A. Orebayo et al / GEOSI Vol 5 No 2 (2020) 226-249

Asfaw, A., Simane, B., Hassen, A., \& Bantider, A. (2018). Variability and time series trend analysis of rainfall and temperature in northcentral ethiopia: A case study in woleka sub-basin. Weather and Climate Extremes, 19, 29-41. doi:10.1016/j.wace.2017.12.002.

Ayanlade, A., Omotoso, F. E., Bisiriyu, L. A., Jegede, M. O., \& Ayanlade, O. S. (2020). Communicating climate change impacts as manifested in extreme weather: a case of newspapers' reports in Nigeria. In Handbook of Climate Services (pp. 401-421). Springer, Cham.

Bae, H., Ji, H., Lim, Y. -., Ryu, Y., Kim, M. -., \& Kim, B. -. (2019). Characteristics of drought propagation in south korea: Relationship between meteorological, agricultural, and hydrological droughts. Natural Hazards, 99(1) doi:10.1007/s11069-019-03676-3.

Buba, L. F., Kura, N. U., \& Dakagan, J. B. (2017). Spatiotemporal trend analysis of changing rainfall characteristics in guinea savanna of nigeria. Modeling Earth Systems and Environment, 3(3), 1081-1090. doi:10.1007/s40808-017-0356-2.

Dammo, M. N., Yadima S. G \& Sangodoyin, A.Y. (2016). Modeling Trends of Temperature Effects on Water Level of Rivers in N/E Nigeria. Civil and Environmental Research. 8(4), 13-17.

Elferchichi, A., Giorgio, G. A., Lamaddalena, N., Ragosta, M., \& Telesca, V. (2017). Variability of temperature and its impact on reference evapotranspiration: The test case of the apulia region (southern italy). Sustainability (Switzerland), 9(12) doi:10.3390/su9122337.

Eludoyin, A. O., Nevo, A. O., Abuloye, P. A., Eludoyin, O. M., \& Awotoye, O. O. (2017). Climate events and impact on cropping activities of small-scale farmers in a part of southwest nigeria. Weather, Climate, and Society, 9(2), 235-253. doi:10.1175/WCAS-D-16-0032.1.

Fitzpatrick, R. G. J., Bain, C. L., Knippertz, P., Marsham, J. H., \& Parker, D. J. (2016). On what scale can we predict the agronomic onset of the west african monsoon? Monthly Weather Review, 144(4), 1571-1589. doi:10.1175/MWR-D-150274.1.

Guevara-Ochoa, C., Medina-Sierra, A., \& Vives, L. (2020). Spatio-temporal effect of climate change on water balance and interactions between groundwater and surface water in plains. Science of the Total Environment, 722 doi:10.1016/j.scitotenv.2020.137886. 
E.A. Adeleke and E.A. Orebayo et al / GEOSI Vol 5 No 2 (2020) 226-249

Ketema, A., \& Siddaramaiah, D. G. (2020). Trend and variability of hydrometeorological variables of tikur wuha watershed in ethiopia. Arabian Journal of Geosciences, 13(3) doi:10.1007/s12517-020-5139-9.

Meshram, S. G., Singh, S. K., Meshram, C., Deo, R. C., \& Ambade, B. (2018). Statistical evaluation of rainfall time series in concurrence with agriculture and water resources of ken river basin, central india (1901-2010). Theoretical and Applied Climatology, 134(3-4), 1231-1243. doi:10.1007/s00704-017-2335-y.

Muthoni, F. K., Odongo, V. O., Ochieng, J., Mugalavai, E. M., Mourice, S. K., HoescheZeledon, I., . . . Bekunda, M. (2019). Long-term spatial-temporal trends and variability of rainfall over eastern and southern africa. Theoretical and Applied Climatology, 137(3-4), 1869-1882. doi:10.1007/s00704-018-2712-1.

NIMET (2008). Nigeria Climate Review Bulletin 2007. Lagos: Nigerian Meteorological Agency.

NIMET (2012). Nigeria Climate Review Bulletin 2012. Lagos : Nigerian Meteorological Agency.

Odekunle, T. O. (2004). Rainfall and the length of the growing season in Nigeria. International Journal of Climatology: A Journal of the Royal Meteorological Society, 24(4), 467-479.

Olaniyan, E., Adefisan, E. A., Balogun, A. A., \& Lawal, K. A. (2019). The influence of global climate drivers on monsoon onset variability in nigeria using S2S models. Modeling Earth Systems and Environment, 5(4), 1405-1428. doi:10.1007/s40808-019-00606-x.

Onakomaiya, S. O. (2000). Ogun State: Local and regional perspectives. Centre for Sandwich Programmes (CESAP), Olabisi Onabanjo University.

Oyewo O.P. (2005). Trend in Rainfall in Northern Nigeria. Thesis University of Ilorin, Nigeria. Pp. 6-19.

Sharma, P. J., Loliyana, V. D., Resmi, S. R., Timbadiya, P. V., \& Patel, P. L. (2018). Spatiotemporal trends in extreme rainfall and temperature indices over upper tapi basin, india. Theoretical and Applied Climatology, 134(3-4), 1329-1354. doi:10.1007/s00704-017-2343-y.

Strahler, A.H \& Strahler, A.N (1988). Modern Physical Geography, Publication: John Wiley \& Sons, Inc, New York, U.S. Pp. 45-82.

Tarfa, P. Y., Ayuba, H. K., Onyeneke, R. U., Idris, N., Nwajiuba, C. A., \& Igberi, C. O. (2019). Climate change perception and adaptation in Nigeria's guinea savanna: 
E.A. Adeleke and E.A. Orebayo et al / GEOSI Vol 5 No 2 (2020) 226-249

Empirical evidence from farmers in nasarawa state, nigeria. Applied Ecology and Environmental Research, 17(3), 7085-7111. doi:10.15666/aeer/1703_70857112.

Tesfaye, S., Birhane, E., Leijnse, T., \& van der Zee, S. E. A. T. M. (2017). Climatic controls of ecohydrological responses in the highlands of northern ethiopia. Science of the Total Environment, 609, 77-91. doi:10.1016/j.scitotenv.2017.07.138.

Umar, D. A., Ramli, M. F., Aris, A. Z., Jamil, N. R., \& Aderemi, A. A. (2019). Evidence of climate variability from rainfall and temperature fluctuations in semi-arid region of the tropics. Atmospheric Research, 224, 52-64. doi:10.1016/j.atmosres.2019.03.023.

Walter, M. W. (1967). Length of the rainy season in Nigeria. The Nigerian Geographical Journal, 10(2), 123-128.

Vellinga, M., Arribas, A., \& Graham, R. (2013). Seasonal forecasts for regional onset of the West African monsoon. Climate Dynamics, 40(11-12), 3047-3070.

Yacoub, E., \& Tayfur, G. (2020). Spatial and temporal of variation of meteorological drought and precipitation trend analysis over whole mauritania. Journal of African Earth Sciences, 163 doi:10.1016/j.jafrearsci.2020.103761.

Zhang, W., \& Zhou, T. (2019). Significant increases in extreme precipitation and the associations with global warming over the global land monsoon regions. Journal of Climate, 32(24), 8465-8488. doi:10.1175/JCLI-D-18-0662.1.

Zhang, Y., \& Fueglistaler, S. (2019). Mechanism for increasing tropical rainfall unevenness with global warming. Geophysical Research Letters, 46(24), 1483614843. doi:10.1029/2019GL086058. 